\title{
Knowledge Synergy Among Lecturers in Public Universities in Rivers State
}

\author{
Amini-Philips Chinyere (PhD) \\ Nwanosike, Victoria Adaeze \\ Educational Management, Faculty of Education, \\ University of Port Harcourt, Choba, Rivers State, Nigeria
}

Doi:10.19044/esj.2018.v14n34p1 ～URL:http://dx.doi.org/10.19044/esj.2018.v14n34p1

\begin{abstract}
Knowledge synergy refers to a continuous knowledge creation process which fuses people with diverse capabilities from diverse places, departments, organizations, institutions and facilities to share, exchange, integrate, combine and transfer their knowledge as they work together to achieve the same goal rather than individuals working independently. Knowledge synergy is pivotal in the achievement of university goals because it kindles productivity. The researchers examined knowledge synergy among lecturers in public universities in Rivers State. Three research questions were answered and three corresponding hypotheses were tested in this study. The study adopted a descriptive research design. The population of the study comprised all the 2330 lecturers in the three public universities in Rivers State, Nigeria. The sample size was 746 lecturers. The stratified random sampling technique using $32 \%$ of the population gave the sample size. The researchers made instrument titled Knowledge Synergy among Lecturers in Public Universities Questionnaire (KSLPUQ), was used for data collection. The instrument contained 43 items that addressed the three research questions. Face and content validities were ensured. The reliability coefficient of 0.92 was obtained with the help of Cronbach alpha. Descriptive statistics: mean and standard deviation was used to answer the three research questions while the z-test statistics was used to test the three null hypotheses at 0.05 level of significance. It was found out among others that lecturers practice knowledge synergy to a very great extent in the three public universities in Rivers State. Again, the types of knowledge synergy practised are academic conferences, workshops, seminars, joint authorship, general staff meetings and one-on-one discussions. It was recommended among others that; heads of department should always pair senior and junior lecturers in the discharge of teaching and non-teaching activities to enrich their knowledge level. Universities' Vice
\end{abstract}


Chancellors, Deans and Provost should also be able to make knowledge synergy a prerequisite for promotion in the university system.

Keywords: Knowledge synergy, Lecturers, Public Universities

\section{Introduction:}

The construct knowledge synergy may prove a little difficult while explaining it, this is because it is derived from two different words-knowledge and synergy. For academic professionalism, it is worthwhile to explain the terms separately before merging them. Knowledge can be considered as the most important strategic resource for ensuring an organisation's long-term success and survival. It is an active human process that involves the understanding and processing of information (thinking) in order to internalize or generate more knowledge. Armstrong (2009), sees knowledge as what people understand about things around here and that it can be described as "know-how" or when it is specific expertise. There are various types of knowledge just as scholars defer in their presentations on the concept of knowledge arising from the diversities in orientation. Yogesh (2002) in his psychology of knowledge identified three types of knowledge, namely; tacit, the explicit, and knowledge conversion. Furthermore, the scholar notes that tacit knowledge is the type of knowledge that cannot be easily visualized and expressed; and that which is highly personal and hard to formalize. The major characteristics of tacit knowledge are that they are embedded in the human brain, cannot be expressed easily, requires extensive personal contact and mentorship network, knowledge maps and video conferencing. While explicit knowledge can be expressed in words and numbers and can easily be communicated and shared in the form of hard data. Its special characteristics are that it can be easily codified, embedded in procedures, represented in documents and transferred with reasonable accuracy. The last type of knowledge identified by Yogesh is knowledge conversion which arises when tacit and explicit knowledge interacts and interchanges into each other in the creative activities of human beings. This type of knowledge is created through the social interaction of two types of knowledge. In another presentation, Hoy and Miskel (2008) present two major kinds of knowledge that are distinguishable. These include general and domain-specific knowledge. General knowledge applies to a variety of situations, for example, general knowledge about how to read or use a word processor is useful in many situations, while domain-specific knowledge relates to a particular task or subject. For example, knowing that there are nine innings in a game is specific to the game of basketball. Similarly, Yogesh (2002), Hoy and Miskel (2008) identified five types of knowledge namely, tacit knowledge, explicit 
knowledge, knowledge conversion, general knowledge and domain-specific knowledge.

Synergy is the creation of a whole that is greater than the simple sum of its parts. The word synergy is derived from the Greek word "Synergia" which means "working together". Yang (2007) notes that Buckminster Fuller invented the word "synergy" by combining the word "synthesis and energy. Mullins (2007) observed that synergy results when the whole is greater than the sum of the component parts and can be expressed simply in terms of $2+2$ $=5$ effect. However, he notes that an organization can also experience negative synergy or the $2+2=$ situation.

Knowledge synergy is an offshoot of other related constructs like knowledge sharing, creation, exchange, embeddedness, alliance and transfer. Knowledge describes a continuous knowledge creation process which fuses people with diverse capabilities from diverse places, departments, organizations, institutions and facilities to share, exchange, integrate, combine and transfer their knowledge especially the tacit as they work together to achieve the same goal rather than individuals working independently.

Ofoegbu (2014) notes that the goal of tertiary education is to develop the intellectual capital of individuals to understand and appreciate their local and school environment and to contribute to national development through high-level relevant manpower training among others. Again, the Federal Republic of Nigeria (FRN, 2014), stipulates that these goals are achievable through teaching, generation and dissemination of knowledge, research and development and virile staff development programmes. For the universities to thrive amidst globalization in the knowledge economy, lecturers need to continuously interact both internally and externally to foster the university interest amidst the meagre resources available to it.

Knowledge synergy in the universities can be done through formal and informal means. Formal when it is institutions that organized it. Informal, when individual put themselves together to achieve their goals. Lecturers in universities carry out knowledge synergy through conferences, seminars and joint authorship. This combination of knowledge and skills has many positive effects on the Nigerian university education system. Having lecturers work together will enable them to develop problem-solving skills, work efficiency, work performance, help solve problems on the spot, exploitation of new ideas, speedy growth and development which is all to the development of Nigerian universities. The consequences of a lack of knowledge synergy to our universities include slow growth and development, rivalry, stiff competition and hoarding of knowledge which directly affect the smooth running of the university system. Nelson (2005) investigated the role of knowledge embeddedness in the creation of synergies in strategic alliances in the Bellingham United States of America and found out that there is a positive 
relationship between knowledge embeddedness and creation of synergy. Agbuigui (2014) investigated academic staff knowledge synergy for quality education delivery in South-South Nigerian universities and found out that teamwork, communication, collaboration and knowledge sharing among academic staff facilitates quality education delivery. Lecturers in the universities will benefit when knowledge is shared and the combination of their individual valuable resources (knowledge) will improve their individual competence which helps them carry out their mandate in academics.

The levels of cooperation, collaboration, teamwork, a combination of efforts and ideas, and togetherness among workers in various organizations account for the achievement of their organizational goals. In knowledge enterprise, synergy is the symbolic process of making knowledge (tacit and explicit) productive and valuable through exchange and combination (Ofoegbu, 2014).

\section{Level of Knowledge Synergy among Lecturers in the Universities}

In this study, the level is seen as the extent which is used to describe knowledge synergy that exists among lecturers in public universities. One of the things achieved through knowledge synergy is innovation. Ayeni and Adedeji (2011) agree with this fact when they stated that knowledge synergy is also necessary to harvest all innovation and invention for the development of Nigerian home fashioned technology. These scholars assert that when people come together with what they have achieved on individual basis innovation and invention will take place as fast as possible. Knowledge synergy facilitates the absorption of information and makes the establishment of joint ventures possible as Reiser and Dempsey (2007) identified. This is to say that scholars learn and acquire information, skills and attitudes from each other. Another level of knowledge synergy is the dissemination of knowledge which is to ensure that knowledge is available to those who need them. Knowledge dissemination occurs through different means (e.g. workshops, conferences, publications and web-based activities). Lecturers in universities in order to achieve knowledge synergy needs to gather what they have on an individual basis and use it to achieve their goal. Yang (2007) comments that if knowledge is shared it appreciates and in so doing organization improves in productivity, creativity, decision making and behavioural change among staff and consequently new competencies and best practice are developed.

Knowledge hoarding occurs sometimes among lecturers. Cong, LiHua and Stonehouse (2007) observed that hoarding breeds a culture of distrust, an unhealthy competition that results to low staff morale and eventual high labour turn over which is a big risk in modern management. Lecturers have to synergize if they must form various parts of the development plans in their institutions. Another level of knowledge synergy is the generation of 
sustainable competitive advantage (Iverson, 2012). Through knowledge synergy, lecturers are able to outperform their competitors and exercise a higher skilled labour force. This is because it enables them to gain ability through attributes and resources to perform at a higher level than others in the same institution or internationally.

\section{Collaboration for Lecturers knowledge synergy in the Universities}

Collaboration is a word that is widely used among individuals, organizations, groups, intellectuals and stakeholders. It describes how groups work together on the same task, not in parallel or separate portions of the task. According to the Oxford Advance Learners Dictionary (2010, p. 277), collaboration is the act of working together with another person or group of people to create or produce something. This can be done between lecturers and their students, lecturer and lecturer, government and teachers etc., to produce extremely useful results in projects, studies and researches. It can also be a piece of work produced by two or more people or groups of people working together.

Researchers around the world collaborate to develop new things. The word collaboration and cooperation are often used interchangeably -by many scholars and this review will adopt that method. Lecturers achieve high knowledge synergy when they are brainstorming with their counterparts and contemporaries. In doing this, a better and high level of reasoning and creative thinking skills, deeper understanding, and lower level of anxiety, stress and high self-esteem is achieved.

In support of the above statement, Halawi, Aronson and McCarthy (2005), Karmal, Manjit and Gurvinder (n-d) Abdus and Balasubramanniam (2004) state that success in today's global economy springs from the fast and efficient exchange of information. These scholars noted that collaboration facilitates innovation and mutual influence through project teams, problemsolving, postmortem session, debriefing, roundtable discussion, workshops, departmental meetings, seminars, casual meetings, peer coaching, cluster and to mention but a few. Collaboration is a powerful means of creating opportunities for innovative knowledge exchange between organizations.

Furthermore, this act of close-mindedness and dependence in relation to the wealth of academics make the lecturers the students and even the entire education system suffer. As a result of this situation, speedy growth and development become a struggle and the standard of academic intellectualism of both lecturers and students continue to experience stunted growth. To improve on this knowledge synergy has been advocated for in different academic settings especially in the Universities. The problem of this study is to find out the extent of knowledge synergy that exists among lecturers in public universities in Rivers State. 


\section{Statement of the Problem}

No institution exists without a certain level of combination, sharing, teamwork, togetherness, communication and cooperation among its staff. With reference to public universities in Rivers State experience has shown that knowledge synergy exists at various levels among lecturers judging from their togetherness in publications, conferences and communication. However, while some do this, others do not feel very comfortable with it and prefer working individually. For the universities to thrive amidst globalization in the knowledge economy lecturers needs to continuously interact both internally and externally as the case may be to foster the universities interest amidst the meagre resources available to it.

For Reiser and Dempsey (2007), knowledge synergy among academics facilitates the absorption of information, makes the establishment of joint ventures possible apart from making it possible for scholars to learn and acquire information, skills and attitudes from each other. Knowledge synergy remains a pattern of life for lecturers and universities that desire to be relevant as there is a need to remain continuously connected to each other for easy growth and development. The problem of the study was to investigate knowledge synergy among lecturers in universities in Rivers State.

\section{Aim and Objectives of the Study}

The study investigated knowledge synergy among lecturers in public universities in Rivers State. In specific terms, the study sought to:

1) Determine the level of knowledge synergy among lecturers in public universities in Rivers State

2) Find out ways' lecturers carry out knowledge synergy in public universities in Rivers State.

3) Find out the extent to which communication among lecturers has enhanced knowledge synergy in public universities in Rivers State.

\section{Research Questions}

The following research questions guided the study:

1) What level of knowledge synergy exists among lecturers in public universities in Rivers State?

2) What are the ways lecturers carry out knowledge synergy in public universities in Rivers State?

3) What is the extent to which communication enhance lecturers' knowledge synergy in public universities in Rivers State?

\section{Hypotheses} level:

The following hypotheses were tested in the study at $0.05 \%$ alpha 
Ho1: There is no significant difference between the mean rating score of experienced and less experienced lecturers on the level of knowledge synergy that exists among them in public universities in Rivers State.

H02: There is no significant difference between the mean rating score of professors and non-professors on ways lecturers carry out knowledge synergy in public universities in Rivers State.

Ho3: There is no significant difference between the mean rating score of lecturers in federal and state universities on ways communication enhance lecturers' knowledge synergy in public universities in Rivers State.

\section{Methodology}

The design used in this study was descriptive survey design in which the researchers collected data from a large sample drawn from a given population and described certain features of the sample as they are at the time of the study and which are of interest to the researchers (Nwankwo, 2013:62). The population of the study consists of all the 2330 lecturers in the 3 public universities in Rivers State (University of Port Harcourt, Rivers State University (RSU) and Ignatius Ajuru University of Education). The population distribution was 1500, 274 and 556 respectively. A sample size of 746 lecturers was obtained using the proportionate stratified randomization (irregular inspecting) method. The instrument was titled "knowledge synergy among lecturers in public universities questionnaire" (KSLPUQ) designed by the researchers was used to collate lecturers' opinion across the universities. The reliability of KSLPUQ was 0.92 while the measurement scales: Level of knowledge synergy subscale (LKSSS) was 0.86 , ways lecturers carry out knowledge synergy subscale (WLCHSS) 0.83 , use of communication in enhancing lecturers' knowledge synergy scale (UCELKSS) was 0.89. Copies of the questionnaire were administered by the researchers with the help of two research assistants. 94\% of the 746 copies of the questionnaire were retrieved for analysis (699). The Mean and Standard Deviation was used to answer the research questions while the z-test at 0.05 level of significance was used to test the stated hypotheses.

\section{Results}

\section{Research Question One}

What level of knowledge synergy exists among lecturers in public universities in Rivers state? 
Table 1: Weighted mean, standard deviation and rank order scores of experienced and less experienced lecturers on the level of knowledge synergy that exists in public universities in Rivers State

\begin{tabular}{|c|c|c|c|c|c|c|c|c|}
\hline \multirow[t]{2}{*}{$\mathrm{S} / \mathrm{N}$} & \multirow{2}{*}{$\begin{array}{l}\text { What is the extent to which you } \\
\text { agree/disagree jib (lie following } \\
\text { statements on (lie level of } \\
\text { knowledge synergy that exists } \\
\text { among lecturers in public } \\
\text { universities in Rivers State? }\end{array}$} & \multicolumn{2}{|c|}{ Experienced } & \multicolumn{2}{|c|}{$\begin{array}{c}\text { Less } \\
\text { Experienced }\end{array}$} & \multirow{2}{*}{$\begin{array}{c}\text { Mean } \\
\text { set } \\
\mathrm{xx} / 2\end{array}$} & \multirow[t]{2}{*}{ Rank } & \multirow[t]{2}{*}{$\underset{\mathbf{k}}{\operatorname{Remar}}$} \\
\hline & & $\bar{x}$ & SD & $\bar{x}$ & SD & & & \\
\hline 1 & $\begin{array}{c}\text { Invention is achieved through } \\
\text { knowledge synergy. At what level } \\
\text { does this operate in your institution? }\end{array}$ & 3.56 & 0.71 & 3.77 & 0.57 & 3.67 & $1^{\mathrm{st}}$ & VHL \\
\hline 2 & $\begin{array}{l}\text { Knowledge synergy facilitates the } \\
\text { absorption of information and uses it } \\
\text { for the establishment of a joint } \\
\text { venture. At what level does this } \\
\text { operate iii your institution? }\end{array}$ & 3.62 & 0.65 & 3.46 & 0.92 & 3.54 & $3^{\text {rd }}$ & VHL \\
\hline 3 & $\begin{array}{c}\text { At what level does knowledge } \\
\text { dissemination among lecturers } \\
\text { operate in your institution? }\end{array}$ & 3.56 & 0.90 & 3.58 & 0.79 & 3.57 & $2^{\text {nd }}$ & VHL \\
\hline 4 & $\begin{array}{l}\text { At what level does incidence of } \\
\text { knowledge hoarding occur among } \\
\text { lecturers in your institution? }\end{array}$ & 3.41 & 0.85 & 3.21 & 1.04 & 3.31 & $5^{\text {th }}$ & $\mathrm{HL}$ \\
\hline 5 & $\begin{array}{l}\text { Knowledge synergy among lecturers } \\
\text { generates competitive advantage } \\
\text { among them. At what level is this } \\
\text { operational in your institution? }\end{array}$ & 3.26 & 0.89 & 3.45 & 1.04 & 3.36 & $4^{\text {th }}$ & HL \\
\hline & $\begin{array}{c}\text { Aggregate mean and standard } \\
\text { deviation }\end{array}$ & 3.48 & 0.80 & 3.49 & 0.87 & 3.49 & & \\
\hline
\end{tabular}

Table 1 shows that the aggregate mean value of 3.49 is above the criterion mean value of 2.50 , therefore, it shows that knowledge synergy exists among lecturers in public universities in Rivers state to a very high level.

\section{Research Question Two}

What are the ways lecturers carry out knowledge synergy in public universities in Rivers state?

Table 2: Weighted mean, standard deviation and rank order of professors and nonprofessors on the ways lecturers carry out knowledge synergy in public universities in

Rivers State

\begin{tabular}{|c|c|c|c|c|c|c|c|c|}
\hline \multirow[t]{2}{*}{$\mathrm{S} / \mathrm{N}$} & \multirow{2}{*}{$\begin{array}{l}\text { The ways lecturers carry out } \\
\text { knowledge synergy in public } \\
\text { universities in Rivers state? }\end{array}$} & \multicolumn{2}{|c|}{ Experienced } & \multicolumn{2}{|c|}{$\begin{array}{l}\text { Less } \\
\text { Experienced }\end{array}$} & \multirow{2}{*}{$\begin{array}{l}\text { Mea } \\
\text { n set } \\
\text { xx } / 2\end{array}$} & \multirow[t]{2}{*}{$\begin{array}{l}\text { Ran } \\
\mathbf{k}\end{array}$} & \multirow[t]{2}{*}{ Remark } \\
\hline & & $\overline{\boldsymbol{x}}$ & SD & $\bar{x}$ & SD & & & \\
\hline 6 & $\begin{array}{l}\text { Lecturers carryout knowledge } \\
\text { synergy through attending } \\
\text { academics conferences }\end{array}$ & 3.11 & $\begin{array}{l}1.2 \\
1\end{array}$ & 3.46 & 0.98 & 3.29 & $3^{\text {rd }}$ & GE \\
\hline
\end{tabular}


7 Lecturers carry out knowledge synergy through attending academic seminars.

$8 \quad$ Lecturers carry out knowledge synergy through attending academic workshops.

9 Lecturers carry out knowledge synergy through joint authorship.

10 Lecturers carry out knowledge synergy through general staff meetings.

11 Lecturers carry out knowledge synergy through one-on-one discussions

$\begin{array}{lllllll}2.98 & \begin{array}{l}1.0 \\ 5\end{array} & 3.42 & 1.12 & 3.20 & 5^{\text {th }} & \text { GE } \\ 3.13 & \begin{array}{l}1.1 \\ 8\end{array} & 3.63 & 0.92 & 3.38 & 1^{\text {st }} & \text { GE } \\ & & & & & \\ 3.33 & 1.2 & 3.21 & 1.25 & 3.27 & 4^{\text {th }} & \text { GE } \\ 3.02 & \begin{array}{l}1.2 \\ 3\end{array} & 3.19 & 1.09 & 3.11 & 6^{\text {th }} & \text { GE } \\ & \begin{array}{l}1.0 \\ 3.17\end{array} & 3.45 & 0.88 & 3.31 & 2^{\text {nd }} & \text { GE } \\ & 4 & & & & & \\ \mathbf{3 . 1 2} & \mathbf{1 . 1} & \mathbf{3 . 3 9} & \mathbf{1 . 0 4} & \mathbf{3 . 2 6} & & \\ & \mathbf{5} & & & & & \end{array}$

Legend: GE- Great Extent

Table 2 shows that items with serial numbers $6,7,8,9,10, \& 11$ have their various mean values above the criterion mean value of 2.50 . This indicated that lecturers usually carry out knowledge synergy through academic conferences; seminar; workshop; joint authorship; general staff meetings and one-on-one discussions.

\section{Research Question Three}

What is the extent to which communication enhance lecturers' knowledge synergy in public Universities in Rivers State?

Table 3: Weighted mean, standard deviation and rank order scores of state and federal lecturers on the extent to which communication enhance lecturers' knowledge synergy in public universities in Rivers State

\begin{tabular}{|c|c|c|c|c|c|c|c|c|}
\hline \multirow[t]{2}{*}{$\mathrm{S} / \mathrm{N}$} & \multirow{2}{*}{$\begin{array}{l}\text { The use of communication in } \\
\text { enhancing lecturers' knowledge } \\
\text { synergy in public universities in } \\
\text { Rivers State? }\end{array}$} & \multicolumn{2}{|c|}{$\begin{array}{l}\text { State } \\
\text { lecturer }\end{array}$} & \multicolumn{2}{|c|}{$\begin{array}{l}\text { Federal } \\
\text { lecturers }\end{array}$} & \multirow{2}{*}{$\begin{array}{l}\text { Mean } \\
\text { set } \\
\mathrm{xx} / 2\end{array}$} & \multirow[t]{2}{*}{$\begin{array}{l}\text { Ran } \\
\mathbf{k}\end{array}$} & \multirow[t]{2}{*}{ Remark } \\
\hline & & $\bar{x}$ & SD & $\overline{\boldsymbol{x}}$ & SD & & & \\
\hline 12 & $\begin{array}{l}\text { Informal communication channel } \\
\text { remains the way for lecturers to } \\
\text { synergize their knowledge as it } \\
\text { attracts lecturers to think outside the } \\
\text { box during interactions. }\end{array}$ & $\begin{array}{l}3 . \\
4 \\
6\end{array}$ & 0.89 & 3.78 & 0.69 & 3.62 & $1^{\text {st }}$ & VGE \\
\hline 13 & $\begin{array}{l}\text { The use of social network applications } \\
\text { help lecturers exchange their ideas and } \\
\text { materials }\end{array}$ & $\begin{array}{l}3 . \\
3 \\
2\end{array}$ & 0.78 & 3.49 & 1.03 & 3.41 & $5^{\text {th }}$ & GE \\
\hline 14 & $\begin{array}{l}\text { Efficient transfer of ideas among } \\
\text { lecturers through communication } \\
\text { improves knowledge synergy. }\end{array}$ & $\begin{array}{l}3 . \\
1 \\
6\end{array}$ & 0.99 & 3.86 & 0.59 & 3.51 & $3^{\text {nd }}$ & VGE \\
\hline 15 & $\begin{array}{l}\text { Participatory communication } \\
\text { motivates lecturers to synergy. }\end{array}$ & $\begin{array}{l}3 . \\
4 \\
1\end{array}$ & 1.05 & 3.61 & 0.89 & 3.51 & $3^{\text {nd }}$ & VGE \\
\hline
\end{tabular}


Lecturers who frequently communicate with each other are free

3 5. from frustrations which may occur in their academic journey.

Lecturers who communicate effectively and efficiently always stand out in intellectual reasoning both locally and internationally

Aggregate mean and standard

deviation

0.76

3.56

0.69

3.54

$2^{\text {nd }}$

VGE

Table 3 shows that the aggregate mean value of 3.51 is above the criterion mean value of 2.50 and therefore implies that communication enhances lecturers knowledge synergy to a very great extent in public universities in Rivers State.

Hypothesis 1: There is no significant difference between the mean rating scores of experienced and less experienced lecturers on the level of knowledge synergy that exists in public universities in Rivers State.

Table 4: z-test calculation of the mean difference between experienced and less experienced lecturers on the level of knowledge synergy that exists.

\begin{tabular}{lccccccc}
\hline Category & N & $\overline{\boldsymbol{x}}$ & SD & Df & z-cal & z-crit & Remarks \\
\hline $\begin{array}{l}\text { Experienced } \\
\text { lecturers }\end{array}$ & 475 & 3.48 & 0.80 & & & & \\
$\begin{array}{l}\text { Less Experienced } \\
\text { lecturers }\end{array}$ & 224 & 3.49 & 0.87 & 697 & 0.14 & 1.96 & Not significant \\
\hline
\end{tabular}

Table 4 shows that experienced lecturers have mean and standard deviation scores of 3.48 and 0.80 while less experienced lecturers have mean and standard deviation scores of 3.49 and 0.87 respectively. With a degree of freedom of 697 at an alpha level of 0.05 , the calculated z-value of 0.14 is less than the critical z-value of 1.96. Therefore, the null hypothesis is accepted. By implication, there is no significant difference between the mean rating scores of experienced and less experienced lecturers on the level of knowledge synergy that exists in public universities in Rivers state.

Hypotheses 2: There is no significant difference between the mean rating score of professors and non-professors on ways lecturers carry out knowledge synergy in public universities in Rivers state.

Table 5: z-test calculation between the mean scores of professors and non-professors on ways lecturers carry out knowledge synergy.

\begin{tabular}{lccccccc}
\hline Category & $\mathbf{N}$ & $\overline{\boldsymbol{x}}$ & SD & Df & z-cal & z-crit & Remarks \\
Professors & 132 & 3.12 & 1.15 & & & & \\
Non-professors & 567 & 3.39 & 1.04 & 697 & 2.45 & 1.96 & $\begin{array}{c}\text { Not } \\
\text { Significant }\end{array}$ \\
\hline
\end{tabular}


Table 5 shows that professors have mean scores of 3.12 and 1.15 respectively while non-professors have mean standard deviation scores of 3.39 and 1.04 respectively and a degree of freedom of 697 at an alpha level of 0.05 . The calculated z-value of 2.45 is greater than the critical z-value of 1.96 . Therefore, the null hypothesis is rejected. By implication, there is a significant difference between the mean rating scores of professors and non-professors on ways lecturers carry out knowledge synergy in public universities in Rivers State.

Hypothesis 3: There is no significant difference between the mean rating score of lecturers in state and federal universities on the ways' communication enhance lecturer's knowledge synergy in public universities in Rivers state.

Table 6: z-test calculation between the mean rating score of lecturers in state and federal universities on the ways' communication enhance lecturer's knowledge synergy in public universities in Rivers state.

\begin{tabular}{lccccccc}
\hline Category & $\mathbf{N}$ & $\overline{\boldsymbol{x}}$ & SD & Df & z-cal & z-crit & Remarks \\
\hline $\begin{array}{l}\text { Lecturers in State } \\
\quad 82\end{array}$ & 3.41 & 0.89 & & & & \\
$\quad \begin{array}{l}\text { Universities } \\
\text { Lecturers in }\end{array}$ & 617 & 3.61 & 0.82 & & & & $\begin{array}{c}\text { Not } \\
\text { significant }\end{array}$ \\
$\begin{array}{l}\text { Federal } \\
\text { Universities }\end{array}$ & & & & & & & \\
\hline
\end{tabular}

Table 6 revealed that lecturers in state universities have mean and standard deviation scores of 3.41 and 0.89 while lecturers in federal universities have mean and standard deviation scores of 3.61 and 0.82 respectively. With a degree of freedom of 697 at an alpha level of 0.05 , the calculated z-value of 2.00 is greater than the critical r-value of 1.96. Therefore, the null hypothesis is rejected. By implication, there is a significant difference between the mean rating score of lecturers in state and federal universities on the ways' communication enhance lecturer's knowledge synergy in public universities in Rivers state.

\section{Discussion of findings}

The first finding revealed that is a high level of knowledge synergy exists among lecturers in public universities in Rivers State. Secondly, the findings show that there is no significant difference between the mean rating scores of experienced and less experienced lecturers on the level of knowledge synergy that exists in public universities in Rivers State. This implies that experience of lecturers does not determine the level of knowledge synergy displayed. This agrees with the findings of Agbugui (2014) who found that there is high levels of teamwork, communication, collaboration and knowledge sharing attitude among academic staff which are a strong 
instrument for ensuring quality education delivery in the university system. Reiser and Dempsey (2007) also reiterated that knowledge synergy facilitates the absorption of information and makes the establishment of joint ventures possible.

Thirdly, the findings also revealed that lecturers usually carry out knowledge synergy through academic conferences; seminar; workshop; joint authorship; general staff meetings and one-on-one discussions. A close examination of the mean set values also revealed that based on the ranking of the mean set obtained for each of the ways' lecturers carry out knowledge synergy, the four most common ways that knowledge synergy is carryout out is through attending academic workshop followed by one-on-one discussion, attending academic conferences and joint authorship. This finding is not surprising because lecturers use these forums to interact and collectively solves problems or address issues. This forum also makes it possible for lecturers to pool their intellectual and financial resources together for the purpose of publishing books, journal articles and other intellectual property, thereby increasing their research productivity as well as building trust among lecturers which enhances interpersonal relationships.

Fourthly, the finding showed that there is a significant difference between the mean rating scores of professors and non-professors on ways lecturers carry out knowledge synergy in public universities in Rivers State. This could be attributed to the level of exposure and experience between the professors and non-professors. The findings are at variance with Agbugui (2014) who noted that knowledge synergy is a continuous process of exploring, exploiting, combining and exchanging the knowledge resource within an organization advantageously to the benefit of lecturers, such that no one is made better off at the expense of another.

The fifth finding revealed that communication enhances lecturers knowledge synergy to a very great extent in public universities in Rivers State. This finding is not surprising but expected. This is because communication is the life-wire of every organization and there can never be meaningful synergy without communication. Furthermore, the fifth finding revealed that in descending order informal communication channel remains the way for lecturers to synergize their knowledge as it attracts lecturers to think outside the box during interactions; lecturers who frequently communicate with each other are free from frustrations which may occur in their academic journey; communication makes efficient transfer of ideas among lecturers possible which in turns improves knowledge synergy; participatory communication motivates lecturers to synergy; lecturers who communicate effectively and efficiently always stand out in intellectual reasoning both locally and internationally; and the use of social network applications help lecturers exchange their ideas and materials. For leaders to issue a command, 
subordinates give feedback and peers interact in an effective manner communication must exist and be effective. Consequently, knowledge synergy among lecturers cannot take place without communication.

While the sixth finding revealed a significant difference between the mean rating scores of professors and non-professors on ways lecturers' carryout knowledge synergy in public universities in Rivers State. This finding corroborates Ofoegbu in Agbugui (2014) who found out that communication process mode and networks are a vehicle for the exchange and combination of knowledge in organizations and society. This finding also agrees with Olih (2007) who found that attendance at the conference, workshop, and seminar are ways lecturers carry out knowledge synergy.

\section{Conclusion}

Knowledge synergy among lecturers in universities in Rivers State exists to a great extent. Majorly, it is carried out through attending academic workshops, conferences, one-on-one discussion and joint authorship. This is a welcome development and tallies with the mandate given to lecturers especially in the area of research and development which leads to generation and dissemination of knowledge. Knowledge synergy is a worthwhile activity and needs to be encouraged as it benefits individual lecturers and their organizations. Knowledge synergy among lecturers improves lecturers' productivity and has a ripple effect on other activities like developing problem-solving skills and improved work performance. Knowledge synergy leads to efficiency because cooperation from many individuals makes the job light. It also promotes research visibility of lecturers because most times the motive for synergizing is to co-author and publish articles in journals which is a requirement for career advancement in universities. Knowledge synergy assists lecturers to publish many articles within a short space of time which will not be possible if they were working individually.

\section{Recommendations}

Based on the findings of this study, the following recommendations are made:

1. Vice-chancellors, Deans and Provosts should make knowledge synergy a prerequisite for promotion in the university system since it has been proven that lecturers achieve faster when they synergize and this improves organizational productivity.

2. Deans and Heads of Department should encourage their lecturers to deeply involve themselves in academic conferences, academic seminars, academic workshops and joint authorship by sponsoring these activities. 
3. Both informal and formal means of communication should be highly encouraged among lecturers to enable them to pass the message across to their colleagues in order to bring growth and development to the university system.

4. The universities should make it a point of necessity to provide the basic needed facilities like internet, electricity and finance that will be used to enhance knowledge synergy among lecturers.

\section{References:}

1. Abdus, S.C. \& Balasubramaniam, S. (2004). Perceptions of teachers about knowledge sharing in schools. Idea Group Publishing (IGP), 15 .

2. Agbugui, N.F. (2014). Academic Staff Knowledge Synergy for quality secondary education delivery in South-South Nigerian Universities. A Ph.D Dissertation, Department of Educational Management, University of Port Harcourt.

3. Armstrong, M. (2009). Armstrong's Handbook of Human Resources management practice. London: Kogan Page.

4. Ayeni, T. \& Adedeji, A. (2011). Educational thoughts and Practice Ibadan codt publications.

5. Blacker, F. (1995). Knowledge, knowledge work and experience. Organizational studies, 16(6). 16-36.

6. Cong. Li-Hua and StoneHouse, G. (2007). Knowledge management in the Chinese public sector: empirical investigation. Journal of technology management in China, 2(3)250-263.

7. Federal Republic of Nigeria (2014). National policy on education. Abuja: Nigerian Education and Development centre.

8. George, P. (1997). Designing knowledge ecosystems for the communities of practice. A paper presented at the conference on advancing organizational capability via knowledge management. 9 (4), 307-3 19.

9. Halawi, J. Aronson, E.J. \& McCarthy, V.R. (2005). Resource-based view of knowledge management for competitive advantage. The electronic journal of knowledge management, 3(2) 16-28.

10. Hoy, W.K \& Miskel, C. (2008). Educational administration: theory, research and practices. New York. McGraw-Hill Higher education.

11. Inversion, S.V. (2012). Multicultural competence for doing social justice: Expanding our Awareness, knowledge, and skills. Journal of Critical thought and Praxis; (1), 54-82.

12. Karmal, K.J., Manjit, S.S. \& Gurvider, K.S. (n.d,). Knowledge sharing among academic staff: A case study of business schools in Kiang 
Valley Malaysia. Retrieved November 01, 2016 from www.ejimelectronicsjournal.org

13. Mullins, L.J. (2007). Management and organizational behavior, (Eight Edition). England Pearson Education.

14. Neilson, B.B. (2005). The role of knowledge embeddedness in the creation of synergies in strategic alliances. Journal of Business Research, 58, 1194-1204.

15. Nonaka, I, \& Takeuchi. H. (1995). The knowledge creating company. How Japanese companies create the dynamics of information. Oxford, London: Oxford University Press.

16. Nonaka. I. (1991). The knowledge creating company. Harvard business school review, 46-104.

17. Nwankwo, O.C. (2013). Practical guide to Research writing for students of research enterprise. Choba: Pam unique publishers.

18. Ofoegbu. Q.K. (2014). Knowledge synergy for academic staff intellectual development in south-south Nigerian Universities. An MED thesis, department of educational management, University of Port Harcourt.

19. Oxford Advanced Learners Dictionary, (2010), (Eight Edition) Oxford University Press.

20. Reiser, R.A. and Dempsey T.V. (2007). Trends and issues in Instructional Design and Technology (2 ${ }^{\text {nd }}$ edition). Upper saddle Rivers, N. J: Pearson.

21. Yogesh, M. (2002). Knowledge transfer. Retrieved October 9th 2016, from www.yogeshrnalhotra.corn.

22. Yang, J. (2007). How does synergy affect the workplace? Performance fact, 33.

23. Olih, I. (2007). Forms of staff development programmes in a tertiary institution in Bayelsa State. Journal of Educational Development 2(1), 63-81. 